\title{
Physiological Characteristics of Germinated Oat (Avena sativa) Extract as Raw Material for Cosmetics
}

\author{
Ji U Hwang ${ }^{1}$, Yung Hun Yang ${ }^{1}$, Tae Boo Choe ${ }^{2 \star}$ \\ ${ }^{1}$ Major in Cosmetic Biology, Department of Bioengineering, Konkuk University, Seoul, Korea \\ ${ }^{2}$ Cosmetics Research Center, Ozbiotech, Seongnam-si, Gyeonggi-do, Korea
}

\author{
*Corresponding author: Taeboo Choe, \\ Cosmetics Research Center, Ozbiotech, \\ 6 th floor, Suan Building, 204 Sunwhan- \\ ro, Jungwon-gu, Seongnam-si, Gyeonggi-do \\ 13204, Korea \\ Tel.: +82316033292 \\ Email: tbchoe@naver.com
}

\section{Received March 25, 2020}

Revised May 15, 2020

Accepted June 2, 2020

Published June 30, 2020

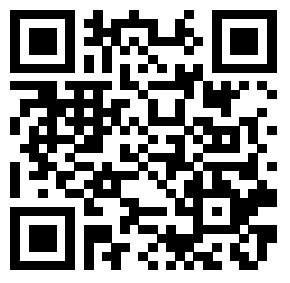

\begin{abstract}
Purpose: This study evaluated the antioxidant and anti-inflammatory ability of germinated and non-germinated oat (Avena sativa) grain for developing a new cosmetic raw material. Methods: Some local oat grains were freeze-dried (cryodesiccated) and extracted using 95\% ethanol to obtain a germinated oat, and the non-germinated oat extract was obtained by redrying. The oat grains were germinated at $20^{\circ} \mathrm{C}$ for 5 days and extracted using the same procedure as described above. Subsequently, the extracts were applied to cultured cells to determine their antioxidant, anti-inflammatory, anti-melanogenic, and anti-aging effects. Results: For the extract of germinated oat, 1,1-diphenyl-2-picryl-hydrazyl (DPPH) radical scavenging activity, and nitric oxide (NO) generation inhibition ability was increased to $112 \%$ and $43 \%$, respectively, compared with the non-germinated. The RAW 264.7 cells stimulated with lipopolysaccharides (LPS) revealed that treatment with the germinated oat extract could downregulate the expression of inflammatory factors, such as cyclooxygenase 2, interleukin 1beta, and interleukin 6 by 35\%,17.5\%, and $22 \%$, respectively. This enhanced anti-inflammatory effect could be as a result of increased avenanthramide during the germination period. Conclusion: Germinated oat grain extract showed an enhanced ability of antioxidant and anti-inflammatory properties. For this reason, the extract of germinated oat grain can be a good source of raw material for cosmetic industry.
\end{abstract}

Keywords: Avena sativa extract, Germination, Avenanthramide, Anti-inflammatory, Cosmetic raw material

\section{Introduction}

귀리는 서유럽에서 많이 경작되고 있는 작물 중 하나로 생산량 의 $95 \%$ 는 사료로 이용되고 나머지 $5 \%$ 만 식량으로 사용되고 있 다. 그러나 쌀보다 단백질 함량이 2 배 이상이고 식이섬유가 풍부 하여 타임지에서 10 대 건강식품으로 선정된 이후 국내에서는 다 이어트 식품으로 그 소비가 점차 증가하고 있다. 귀리에서 발견 되는 주요 폴리페놀류들로는 protocatechuic, syringic, vanillic, p-hydroxybenzoic, gallic, p-coumaric, o-coumaric, caffeic acid 등이 있으며 그 중에서도 아베난쓰라마이드(Avenanthramide)는 귀 리에만 존재하는 폴리페놀의 일종으로 항산화, 항염, 항암, 항혈전 등 다양한 생리활성 작용이 우수하다고 알려져 있다(Soycan et al., 2019). 귀리에서 발견되는 아베난쓰라마이드는 여러 가지 종류가
있으나 N-cinnamoyl anthranilic acid의 잔기에 따라 $\mathrm{p}$-coumaric acid가 결합된 아베난쓰라마이드 A, ferulic acid가 결합된 아베난 쓰라마이드 B, caffeic acid가 결합된 아베난쓰라마이드 C가 주종 을 이루고 있다. 아베난쓰라마이드는 현재 시중에서 판매되고 있 는 항 알레르기성 의약품인 tranilast와 매우 유사한 구조를 가지 고 있으며, 이러한 이유로 해서 항염(anti-inflammatory) 및 항 동 맥경화(anti-atherogenic) 효과에 대해 많은 연구가 이루어지고 있 다(Maydani, 2009). 특히 아베난쓰라마이드는 대식세포가 염증유 발 물질을 방출하거나 단핵구세포가 혈관 내피세포에 부착하는 것 을 억제하는 것으로 알려져 있다(Liu et al., 2004; Dhakal et al., 2019). 아베난쓰라마이드는 특히 건성피부의 가려움증 해소에 탁월 한 효과가 있는 것으로 알려져 있는데(Sur et al., 2008; Perrelli et al., 2018) 이러한 이유로 해서 서유럽에서는 귀리 추출물이 화장품 
소재로 널리 이용되고 있다.

발아는 곡류들의 화학적 조성을 광범위하게 변화시키는 효과가 있다. 맥주를 만들기 위해 보리를 물에 불린 후 발아시키면 보리 내 의 단백질, 비타민, 미네랄 등의 생분해성이 증가하고 생리활성 기능 이 향상된다(Bamforth \& Barclay, 1993). 호밀은 발아를 통해 식물 성 스테롤, 엽산, 리그난, 페놀화합물 등이 증가한다(Katina et al., 2007). 귀리의 경우에도 이와 비슷한 현상을 보이는데 귀리 내의 아 베난쓰라마이드 농도는 귀리를 발아시킬 경우 발아 전에 비해 아베 난쓰라마이드 농도가 월등히 증가한다고 보고하고 있다(Xu et al., 2009). 따라서 본 연구에서는 이러한 점에 착안하여 현재 화장품 소 재로 많이 이용되고 있는 알곡 형태의 귀리를 5 일정도 발아시켜 얻 어진 발아 귀리 추출물의 생리활성적인 특성을 비교 연구함으로써, 알곡 귀리보다 우수한 화장품 소재로서의 가능성을 조사하여 보았 다.

\section{Materials and Methods}

\section{1. 실험 재료 및 세포배양}

실험에 사용된 lipopolysaccharide (LPS), $\alpha$-melanocyte stimulating hormone ( $\alpha-\mathrm{MSH})$, mushroom tyrosinase, $\mathrm{L}-3,4-$ dihydroxyphenylalanin (L-DOPA)는 Sigma (USA)사에서 구입 하였다. 실험에 사용한 세포주 $\mathrm{HDF}$ (human dermal fibroblasts), B16-F10 (melanoma) 세포, RAW264.7 (rat macrophage) 세포는 한국세포주은행으로부터 분양받아 사용하였다. $10 \%$ fetal bovine serum (FBS; Gibco, USA), 0.22\% sodium bicarbonate를 첨가한 Dulbeccos modified Eaglesmedium (DMEM, Gibco)을 기본배지로 하여 $37^{\circ} \mathrm{C}, 5 \% \mathrm{CO}_{2}$ 습윤 배양기(Sanyo, Japan)에서 배양하였다.

\section{2. 귀리 및 발아 귀리 추출물 준비}

귀리는 시중에서 2018년 국내산 귀리 알곡을 구입하여 사용하 였다. 귀리의 발아는 Skoglund (2008)가 제시한 방법을 이용하여 발 아시켰다. 간략하면, 먼저 귀리 알곡을 $1 \%$ 차아염소산 용액에 $30 \mathrm{~s}$ 담궈 표면을 살균한 후, 물에 적신 키친 타올을 바닥에 깐 페트리 디 쉬에 올려놓는다. 이 페트리 디쉬를 온도 $20^{\circ} \mathrm{C}$, 습도 $45 \%$ 인 배양기
(Lab Companion, Korea) 내에서 5일간 배양한다. 배양기에서 꺼 낸 발아 귀리는 동결 건조 후 믹서기를 이용하여 가루 형태로 만들고 $95 \%$ 에탄올 $(1: 5 \mathrm{w} / \mathrm{v})$ 을 이용하여 발아 귀리 추출물을 생산한다. 이 후 세포 실험에 사용할 귀리 추출물은 다시 동결 건조하여 에탄올이 완전히 제거된 분말형태의 귀리 추출물을 배지에 녹여 이용하였다. 귀리 알곡도 가루 형태로 만들고 동일한 방법을 이용하여 추출하였 다.

\section{3. 아베난쓰라마이드 농도 측정}

$\mathrm{HPLC}$ 를 이용한 귀리 추출물의 아베난쓰라마이드 농도 측정 조건 은 Table 1 과 같다.

\section{4. 세포독성 측정}

귀리 추출물의 세포 독성측정과 실험에 사용될 농도 범위를 결 정하기 위해 96 well plate에 well당 $3 \times 10^{4}$ cells/well의 농도로 분 주하여 $24 \mathrm{~h}$ 전 배양하였다. 세포가 well plate에 충분히 부착된 것 을 확인한 후 주어진 귀리 추출물 농도가 되도록 첨가하고 무혈 청 배지를 이용하여 $48 \mathrm{~h}$ 동안 배양하였다. 배양한 세포는 배양액 을 neutral red (NR) solution이 $1 \%$ 포함된 무혈청 배지로 교환하 여 $3 \mathrm{~h}$ 배양한 다음 현미경 하에서 $\mathrm{NR}$ 의 결정화 유무를 확인하였 다. 세포고정액으로 formaldehyde 용액 10\%가 첨가된 phosphate buffered saline (PBS)을 각 well에 $100 \mu \mathrm{L}$ 로 $20 \mathrm{~min}$ 처리하여 고정하였다. NR desorb solution (1\% glacial acetic acid, 49\% ethanol, $50 \%$ distilled water)을 각 well에 $100 \mu \mathrm{L}$ 씩 분주하여 세포 내의 neutral red를 추출하고 microplate reader (Bio-Rad, USA) 를 이용하여 $540 \mathrm{~nm}$ 에서 흡광도를 측정하였다. 세포 생존율은 아래 의 식에 따라 계산하였다

세포생존율 $(\%)=[($ 시료첨가군의 O.D. at $540 \mathrm{~nm}) /($ 시료무첨가군 의 O.D. at $540 \mathrm{~nm}] \times 100$

\section{5. 항산화력 측정}

1) 총 폴리페놀 함량 측정

귀리 추출물의 총 폴리페놀 함량 측정은 Folin-Denis 방법을 수 정하여 Folin-Ciocalteaus phenol reagent가 추출물의 페놀성 화합 물에 의해 환원되어 몰리브덴 청색으로 발색되는 원리를 이용하여

\section{Table 1. HPLC conditions of Avena sativa extract}

\begin{tabular}{lc}
\hline Column & Kinetex C18 $(4.6 \times 250 \mathrm{~mm}, 5 \mu \mathrm{m})$ \\
Guard column & UHPLC C18 \\
Column temperature & $35^{\circ} \mathrm{C}$ \\
Eluents & (A) $50 \mathrm{mM}$ phosphoric acid, (B) Acetonitrile \\
Flow rate & $0.8 \mathrm{~mL} / \mathrm{min}$ \\
Wave length & $350 \mathrm{~nm}$ \\
Injection volume & $10 \mu \mathrm{L}$ \\
\hline
\end{tabular}


정량하였다(Gutfinger, 1981). 귀리 추출물 $0.2 \mathrm{~mL}$ 에 3차 증류수 5 $\mathrm{mL}$ 를 가한 후 Folin-Ciocalteaus phenol reagent (Sigma) 시약을 $0.5 \mathrm{~mL}$ 씩 차례로 가한 다음 실온에 $3 \mathrm{~min}$ 간 방치한 후 $2 \% \mathrm{Na}_{2} \mathrm{CO}_{3}$ 용액 $1 \mathrm{~mL}$ 를 혼합하고 다시 실온에 $1 \mathrm{~h}$ 방치한 후 microplate reader를 이용하여 $729 \mathrm{~nm}$ 에서 흡광도를 측정하였다. Caffeic acid (Sigma)를 표준물질로 사용하여 0-100 $\mu \mathrm{g} / \mathrm{mL}$ 농도로 제조한 후 시료와 동일한 방법으로 분석하여 흡광도로 상대적인 폴리페놀 함 량 변화를 조사하였다

\section{2) 총 플라보노이드 함량 측정}

귀리 추출물의 총 플라보노이드 함량은 Moreno et al. (2000) 방 법을 이용하여 측정하였다. 추출물 $0.5 \mathrm{~mL}$ 농도의 시료 액에 $10 \%$ aluminium nirate $0.1 \mathrm{~mL}$ 과 $1 \mathrm{M}$ potassium acetate $0.1 \mathrm{~mL}$ 및 ethanol $4.3 \mathrm{~mL}$ 를 차례로 가하여 혼합하여 실온에서 $40 \mathrm{~min}$ 방치 한 후 microplate reader를 이용하여 $415 \mathrm{~nm}$ 에서 흡광도를 측정하 였다. Quercetin (Sigma)을 표준물질로 사용하여 0-100 $\mu \mathrm{g} / \mathrm{mL}$ 농 도로 제조한 후 시료와 동일한 방법으로 분석하여 흡광도로 상대적 인 플라보노이드 함량 변화를 조사하였다.

\section{3) $\mathrm{DPPH}$ radical 소거능 측정}

귀리 추출물의 $\mathrm{DPPH}$ 라디칼 소거활성은 Blois의 방법을 이 용하여 측정하였다(Blois, 1958). 귀리 추출물을 ethanol에 1-10 $\mathrm{mg} / \mathrm{mL}$ 의 농도로 용해시킨 후 96 well plate에 $0.2 \mathrm{mM}$ 로 용해시킨 $\mathrm{DPPH}$ (Sigma) 용액 $180 \mu \mathrm{L}$ 와 시료액 $20 \mu \mathrm{L}$ 씩 첨가하고 $37^{\circ} \mathrm{C}$ 에 서 $30 \mathrm{~min}$ 반응시켰다. 반응 후 microplate reader를 이용하여 517 $\mathrm{nm}$ 에서 흡광도를 측정하였으며 표준물질은 ascorbic acid를 사용하 였다.

$\mathrm{DPPH}$ 라디칼소거활성 $(\%)=100-[($ 시료첨가군 흡광도 $) /$ 시료무첨 가군의 흡광도 $) \times 100$

\section{6. 항염 효과 측정}

1) Nitric oxide (NO) 생성 저해능 측정

Greenstock (1983)의 방법에 따라 귀리 추출물의 NO 생성 저해 능을 측정하기 위하여 세포 배양액 내 $\mathrm{NO}$ 양을 측정하였다. RAW 264.7 세포를 96 well plate에 well 당 $5 \times 10^{4}$ cells의 농도로 분주하 고 $24 \mathrm{~h}$ 동안 전 배양 하였다. 배양 후 배지를 제거하고 LPS $1 \mu \mathrm{g} /$ $\mathrm{mL}$ 이 포함된 배지에 귀리 추출물을 각 농도별로 가하여 $48 \mathrm{~h}$ 동 안 배양하였다. 새로운 plate에 배양된 세포 배양 상층액 $100 \mu \mathrm{L}$ 와 griess reagent (Sigma) $100 \mu \mathrm{L}$ 를 가하여 차광된 상태에서 $10 \mathrm{~min}$ 간 반응시키고 $540 \mathrm{~nm}$ 에서 흡광도를 측정하였으며 LPS 처리군과 비교하여 백분율로 표시하였다.

$\mathrm{NO}$ 생성 저해능 $(\%)=100-[($ 시료첨가군의 O.D. at $540 \mathrm{~nm}) /($ 시 료첨가군의 O.D. at $540 \mathrm{~nm})] \times 100$
2) 세포내 염증인자 발현 저해능 측정

발아 귀리 추출물의 항염 효과를 좀 더 심층적으로 조사하 기 위하여 LPS 처리에 의하여 활성화된 RAW 264.7 세포에서 염증 매개 유전자인 inducible nitric oxide synthase (iNOS)와 cyclooxigenase-2 (COX-2)의 발현 및 염증인자인 $\mathrm{IL}-1 \beta, \mathrm{IL}-6$ 의 발현에 미치는 영향을 조사하였다. 6well plate에서 세포를 배 양하고 수확한 후 $\mathrm{PBS}$ 로 수세한 다음 원심분리하여 상등액을 제 거하고 lysis buffer (150mM NaCl, 50mM Tris-Cl (pH7.4), 1\% NP-40, 0.5\% deoxycholic acid, 0.1\% SDS, protease inhibitor cocktail(Roche, USA))를 첨가해 얼음에 두고 $5 \mathrm{~min}$ 마다 vortex하 면서 $30 \mathrm{~min}$ 반응시켰다. 반응액을 $4^{\circ} \mathrm{C}, 12,000 \mathrm{rpm}$ 에서 $30 \mathrm{~min}$ 원심분리하여 상등액만을 취하였다. 상등액은 Bradford solution $(\mathrm{Bio}-\mathrm{Rad})$ 을 이용하여 단백질 정량하였다. 이로부터 동량의 단백 질을 취하여 sample buffer (12mM Tris-Cl (pH6.8), $5 \%$ glycerol, $0.4 \%$ SDS, 7mM 2- $\beta$-mercaptoethanol, $0.02 \%$ bromophenol blue)와 혼합한 후 $100^{\circ} \mathrm{C}$ 에서 $5 \mathrm{~min}$ 간 끓여 전기영동 샘플을 준비 하였다. 전기영동은 $12 \% \mathrm{SDS}-\mathrm{PAGE}$ gel을 이용하여 실시하였다. 전기영동이 끝난 단백질은 cold transfer buffer (25 mM Tirs, 192 $\mathrm{mM}$ glycine, $20 \%$ methanol)을 이용하여 $100 \mathrm{~V}$ 로 한 시간 동안 transfer 하여 nitro cellulose membrane (Protran Nitro-cellulose membrane, UK)으로 이동시켰다. 이동이 끝난 membrane은 blocking solution(5\% skim milk in TBS-T (10 mM Tirs-Cl, $\mathrm{pH}$ 7.5), $150 \mathrm{mM} \mathrm{NaCl}, 0.05 \%$ Tween 20)에 넣고 한 시간 동 안 교반시켰다. Blocking이 끝난 membrane은 primary antibody 가 첨가된 용액 $(5 \%$ skim milk in $\mathrm{TBS}-\mathrm{T})$ 에 담가 $4^{\circ} \mathrm{C}$ 에서 $18 \mathrm{~h}$ 동 안 교반하였다. Primary antibody 처리 후 membrane을 TBS-T 로 4회 수세한 후 secondary antibody가 첨가된 용액에 담가 상온 에서 $2 \mathrm{~h}$ 동안 반응시켰다. 반응 후 TBS-T로 4회 수세하고 ECL (Electrochemiluminescence) solution (Super signal west pico solution, Pierce, USA)을 처리한 다음 Las 3000 (Fuji, Japan)에 감광하여 분석하였다.

\section{7. 멜라닌 생성억제 효과 측정}

\section{1) 세포내 멜라닌 생성억제 효과}

B16F10 melanoma 세포를 이용하여 귀리 추출물의 멜라닌 생성 억제능을 측정하였다. 96 well plate에 B16F10 세포를 $2 \times 10^{3}$ cells/ well의 농도로 분주하고, 세포가 바닥에 부착할 수 있도록 $24 \mathrm{~h}$ 동 안 전 배양하였다. 세포 부착 확인 후 멜라닌 생성을 촉진하기 위하 여 혈청 $5 \%$ 와 $\alpha-\mathrm{MSH} 10 \mu \mathrm{M}$ 이 포함된 배지로 갈아준 후, 시료를 각 농도별로 처리하였다. 분비된 멜라닌의 양은 microplate reader 를 이용하여 $405 \mathrm{~nm}$ 에서 측정하였고 멜라닌 생성량을 시료 무첨가 군과 비교하여 백분율로 표시하였다

멜라닌 생성 저해율 $(\%)=100-[($ 시료첨가군의 O.D. at $405 \mathrm{~nm})] /$ (시료무첨가군의 O.D. at $405 \mathrm{~nm}$ ) $] \times 100$ 

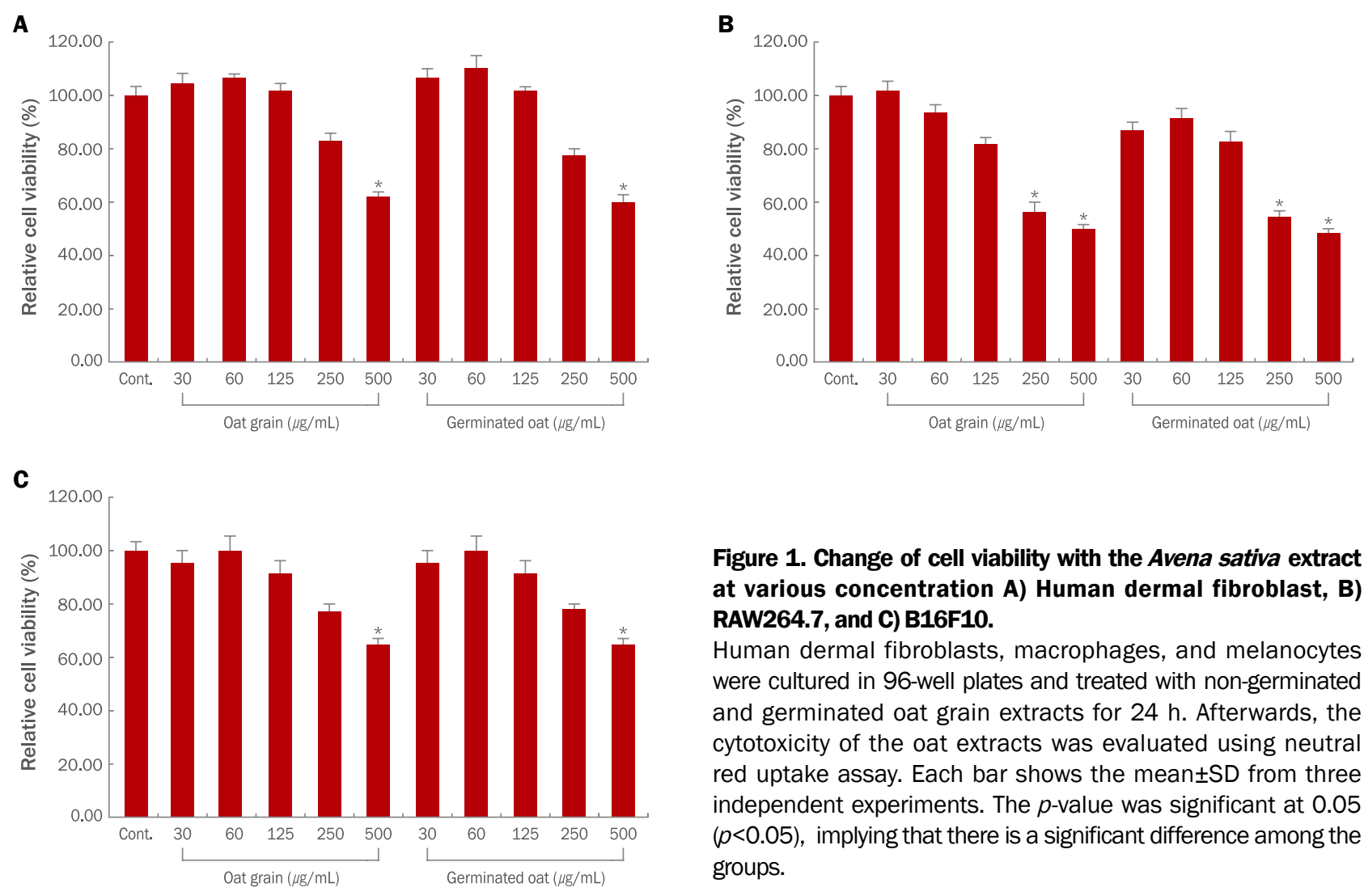

Figure 1. Change of cell viability with the Avena sativa extract at various concentration A) Human dermal fibroblast, B) RAW264.7, and C) B16F10.

Human dermal fibroblasts, macrophages, and melanocytes were cultured in 96-well plates and treated with non-germinated and germinated oat grain extracts for $24 \mathrm{~h}$. Afterwards, the cytotoxicity of the oat extracts was evaluated using neutral red uptake assay. Each bar shows the mean $\pm S D$ from three independent experiments. The $p$-value was significant at 0.05 $(p<0.05)$, implying that there is a significant difference among the groups.

2) Mushroom tyrosinase를 이용한 효소 저해 효과

$\mathrm{L}-\mathrm{DOPA}$ 를 기질로 사용하여 tyrosinase 저해능을 측정하였다. 효소액은 mushroom tyrosinase (5.8 mg solid; 4276 units/mg solid, Sigma) $1 \mathrm{mg} / 20 \mathrm{~mL}$ 의 농도로 $0.1 \mathrm{M}$ phosphate buffer (pH 6.0)에 녹여 사용하였다. L-DOPA는 $1 \mathrm{mg} / \mathrm{mL}$ 의 농도로 sodium phosphate buffer (0.1 M, pH 6.0)로 완전히 녹여 $100 \mu \mathrm{L}$ 을 취하 고, 여기에 귀리 추출물 $50 \mu \mathrm{L}$, tyrosinase $50 \mu \mathrm{L}$ 를 96 well plate 에 순서대로 분주한 후 $37^{\circ} \mathrm{C}$ 에서 $3 \mathrm{~min}$ 반응시킨 후 microplate reader를 이용하여 $475 \mathrm{~nm}$ 에서 흡광도를 측정하였다. 대조군으로 는 arbutin을 $100,200,300 \mu \mathrm{g} / \mathrm{mL}$ 농도로 실험군과 동일하게 진행 하였다.

\section{Matrix metalloproteinase-1 (MMP-1) 발현 측정}

$\mathrm{HDF}$ 세포를 $96 \mathrm{well}$ 에 well 당 $3 \times 10^{4} \mathrm{~T}$ 씩 부착시켜 overnight 시킨다. Well의 상등액을 버리고 $\mathrm{DMEM}$ 에 녹인 추출물을 농도별 로 처리 한 후 UVB를 $20 \mathrm{~min}$ 간 조사하고 $24 \mathrm{~h}$ 배양한다. 배양 이 끝나면 배양액 속에 분비된 MMP-1의 양을 측정하기 위해 배 양 상등액 $100 \mu \mathrm{L}$ 을 96 well plate에 첨가한 후 overnight시킨다. 그 다음날 상등액 제거 후 washing buffer로 3 번 washing (Tween 20 in PBS)한다. Blocking buffer (0.1\% BSA in PBS) $100 \mu \mathrm{L}$ 처

리 후 $37^{\circ} \mathrm{C}$ 에서 $1 \mathrm{~h}$ 정치한다. 상등액 제거 후 washing buffer로 3 번 washing (Tween 20 in PBS)한다. 1.000배 회석 한 후 primary antibody(anti-MMP-1 mouse antibody (Sigma) in 0.1\% BSA/ well)를 $50 \mu \mathrm{L}$ 처리 후 $37^{\circ} \mathrm{C}$ 에서 한 시간 정치한다. 상등액 제거 후 washing buffer로 3번 washing (Tween 20 in PBS)한다. 4.000배 회석 한 secondary antibody (anti-mouse IgG antibody in $0.1 \%$ $\mathrm{BSA} /$ well, Sigma)를 $50 \mu \mathrm{L}$ 처리 후 $37^{\circ} \mathrm{C}$ 에서 한 시간 정치한다. 상 등액 제거 후 washing buffer로 5번 washing (Tween 20 in PBS) 한다. $1 \mathrm{mg} / \mathrm{mL}$ 의 농도로 녹인 $\mathrm{pNPP} 100 \mu \mathrm{L}$ 를 각 well당 처리 후 $37^{\circ} \mathrm{C}$ 암실에서 한 시간 정치한 후 $405 \mathrm{~nm}$ 흡광도에서 측정하였다.

\section{9. 통계분석 방법}

본 연구의 결과 값은 3 회 반복 실험을 실시하여 평균표준편 차로 표시하였다. 각 실험에서 Student's t-test를 이용하여 검 증하였고, 유의수준을 0.05 ( $\left.{ }^{*} p<0.05\right), 0.01$ ( $\left.{ }^{* *} p<0.01\right), 0.001$ $\left.{ }^{* * *} p<0.001\right)$ 일 경우 통계적으로 유의하다고 검증하였다.

\section{Results and Discussion}

\section{1. 귀리 추출물의 세포독성}


A

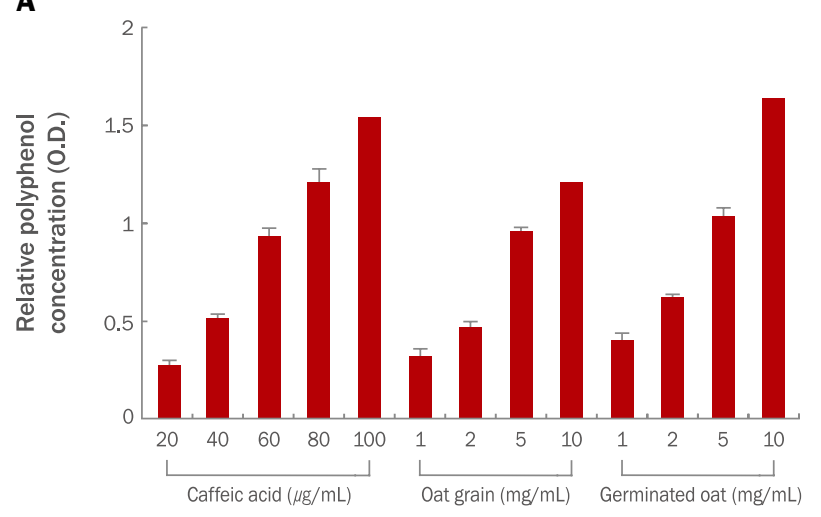

C

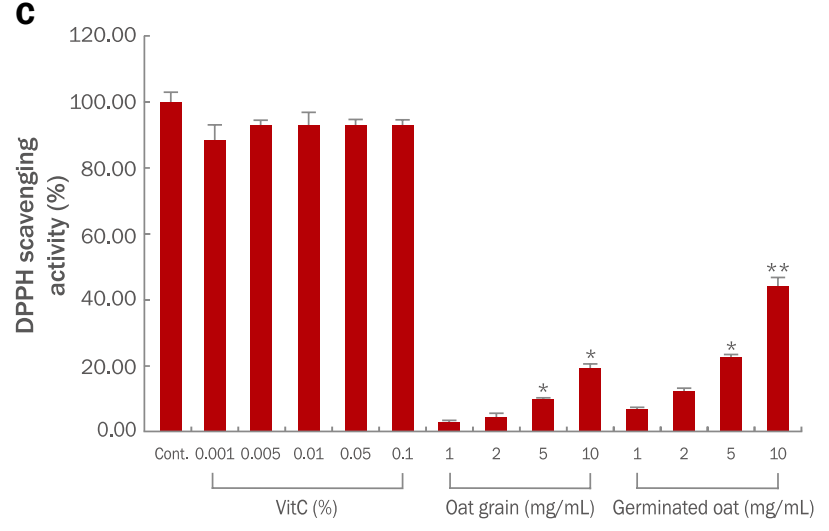

귀리 추출물들의 세포 독성을 조사하기 위하여 실험 대상 세포 인 HDF, RAW264.7, B16F10 세포 배양액에 귀리추출물을 30, 60, $125,250,500 \mu \mathrm{g} / \mathrm{mL}$ 의 농도로 처리한 결과는 Figure 1 과 같다. $\mathrm{HDF}$ 세포와 B16F10 세포 배양에서는 $250 \mu \mathrm{g} / \mathrm{mL}$ 이상의 농도에서 세포 성장을 억제하는 것으로 나타났고, RAW 세포에서는 $125 \mu \mathrm{g} /$ $\mathrm{mL}$ 이상의 농도에서 세포 성장을 억제하는 것으로 나타났다. 따라 서 이후의 세포 실험에서 $\mathrm{HDF}$ 와 $\mathrm{B} 16 \mathrm{~F} 10$ 세포는 귀리 추출물 200 $\mu \mathrm{g} / \mathrm{mL}$ 이하의 농도에서, $\mathrm{RAW}$ 세포는 $100 \mu \mathrm{g} / \mathrm{mL}$ 이하의 농도에서 실험을 진행하였으며 발아 후 귀리 추출물도 같은 농도 범위 내에서 실험을 진행하였다.

\section{2. 발아 기간 중 귀리 추출물의 항산화 활성 변화}

1) 총 폴리페놀 및 총 플라보노이드 변화

화장품에서 식물 추출물을 많이 사용하는 이유 중 하나는 이들이 가지고 있는 높은 항산화활성 때문이다. 그리고 총 폴리페놀 함량과

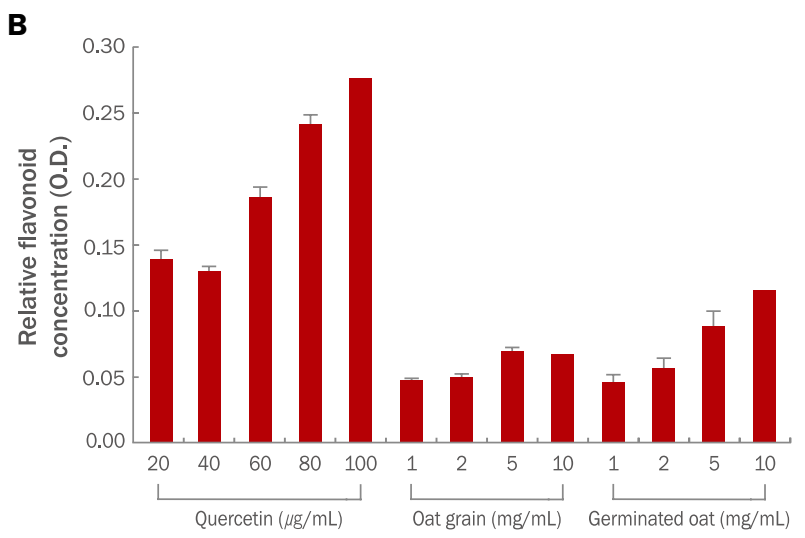

Figure 2. Change of antioxidant ability of Avena sativa extract at various concentration $A$ ) total polyphenol, B) total flavonoid, and C) DPPH radical scavenging activity.

(A) In total polyphenol contents of oat extracts, caffeic acid was used as a positive control; (B) In total flavonoid contents of oat extracts, quercetin was used as the positive control; (C) While in DPPH radical scavenging activity of oat extract, Ascorbic acid was used as the positive control. Each bar shows the mean \pm SD from three independent experiments. ${ }^{*} p<0.05$ compared with control.

총 플라보노이드 함량은 추출물의 항산화활성과 밀접한 관계가 있 으므로 이들을 측정하여 추출물의 항산화능을 알아볼 수 있다. 발아 전, 후 귀리 추출물의 폴리페놀 양과 플라보노이드 양을 측정한 결 과는 Figure 2 와 같다. 총 폴리페놀 함량은 추출물 농도 $1 \%(10 \mathrm{mg} /$ $\mathrm{mL}$ )에서 알곡은 1.1 (optical density), 발아 귀리는 1.76으로 나타 나 알곡에 비해 발아 귀리는 약 $60 \%$ 정도 높게 나타났으며(Figure $2 \mathrm{~A}$ ), 총 플라보노이드 함량은 알곡은 0.07 (optical density), 발아 귀 리는 0.13 으로 나타나 알곡에 비해 발아 귀리는 약 $86 \%$ 정도로 높게 나타났다(Figure 2B).

발아 귀리가 알곡보다 폴리페놀 함량이 $60 \%$ 정도로 월등히 높게 나오는 것은 발아 과정에서 새로운 폴리페놀류들이 생성되기 때문이 다. 그 중에서도 귀리의 발아 과정에서는 귀리만이 가지고 있는 대 표적인 폴리페놀류인 아베난쓰라마이드의 농도가 크게 증가하기 때 문이다. 귀리 알곡을 $20^{\circ} \mathrm{C}$ 에서 5 일간 배양하였을 때 배양 일수에 따 른 추출물 내의 아베난쓰라마이드 농도 변화는 Table 2 와 같다. 실

Table 2. Change in concentration of avenanthramide A, B, C during the germination period of Avena sativa

(Unit: $\mu \mathrm{g} / \mathrm{mL}$ )

\begin{tabular}{cccc}
\hline Germination period (day) & Avenanthramide A & Avenanthramide B & Avenanthramide C \\
0 & 0.073 & 0.066 & 0.028 \\
3 & 0.087 & 0.080 & 0.028 \\
5 & 0.101 & 0.087 & 0.027 \\
\hline
\end{tabular}




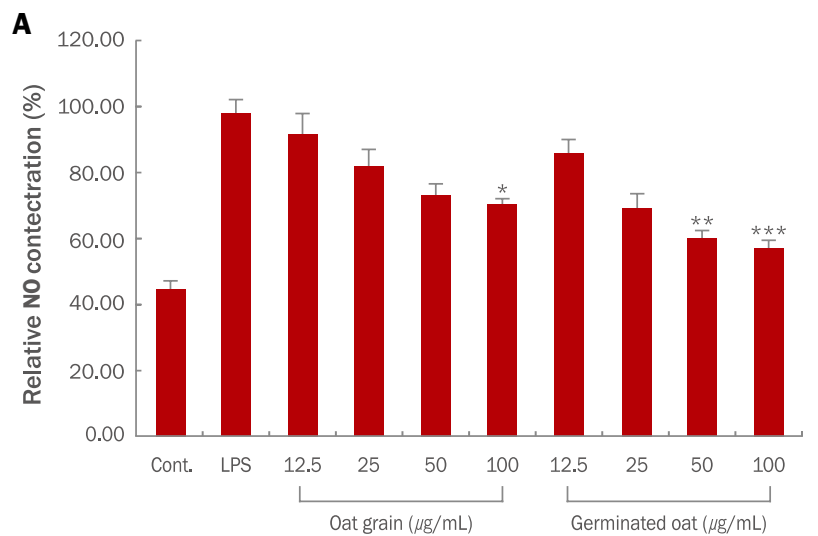

Figure 3. Effect of Avena sativa extract on the production of nitric oxide (NO) in the culture media of RAW264.7 stimulated with LPS.

RAW 264.7 macrophages were cultured in 96-well plate, while the indicated dose of oat grain extracts were treated with LPS. NO was assayed to evaluate the anti-inflammatory effect. Dosedependent and oat extract-treated macrophages decreased the nitric oxide production. Each bar shows the mean \pm SD from three independent experiments. NO, nitric oxide; ${ }^{*} p<0.05,{ }^{* *} p<0.01$ compared with control.

험 결과에 따르면 아베난쓰라마이드 $\mathrm{A}$ 의 농도는 발아 전 0.073 에 서 5 일 발아 후에는 $0.101 \mu \mathrm{g} / \mathrm{mL}$ 으로, 아베난쓰라미아드 $\mathrm{B}$ 의 농도 는 발아 전 0.066 에서 5 일 발아 후에는 $0.087 \mu \mathrm{g} / \mathrm{mL}$ 으로 각각 $38 \%$ 와 $31 \%$ 씩 증가하는 것으로 나타났다. 그러나 아베난쓰라마이드 C 의 경우에는 별다른 변화가 없었다. 그러나 전체적으로 보았을 때 발
아가 진행되면서 귀리 추출물 내의 아베난쓰라마이드의 농도는 확 실하게 증가하는 것으로 보인다. Skoglund et al. (2008)에 따르면 귀리가 발아하는 과정에서 아베난쓰라마이드 생성에 관련된 효소 인 hydroxyanthranilate $\mathrm{N}$-hydroxycinnamoyl transferase (HHT) 가 증가함에 따라 아베난쓰라마이드의 농도도 귀리 종류에 따라 63$125 \%$ 까지 증가한다고 보고하고 있다. 또 Xu et al. (2009)의 연구 에 따르면 귀리가 발아되는 과정에서 총 폴리페놀 양은 $1.65 \mathrm{mg} / \mathrm{g}$ 에서 $2.62 \mathrm{mg} / \mathrm{g}$ 으로 약 $58 \%$ 증가하였고, 아베난쓰라마이드 총 양 은 $121.8 \mu \mathrm{g} / \mathrm{g}$ 에서 $180.4 \mu \mathrm{g} / \mathrm{g}$ 으로 $48 \%$ 가량 증가하는 것으로 보 고하였다. 이처럼 귀리의 발아 과정에서 총 폴리페놀 함량이 증가하 는 것은 결합 형태의 폴리페놀이 프리 폴리페놀로 바뀌면서 추출 과 정에서 쉽게 유리되기 때문이고, 아베난쓰라마이드가 증가하는 것은 아베난쓰라마이드 형성에 관여하는 효소중 하나인 HHT가 증가하여 anthranilic acid와 hydroxycinnaloyl-CoA ester와의 반응이 증가하 기 때문이다.

\section{2) $\mathrm{DPPH}$ 소거활성 변화}

귀리 추출물의 항산화활성을 알아보기 위하여 $\mathrm{DPPH}$ 소거활성 효 과를 측정하였다(Figure $2 \mathrm{C}$ ) 추출물 $1 \%$ 농도에서 $\mathrm{DPPH}$ 소거활성 능력은 알곡의 경우 $20.58 \%$, 발아 귀리의 경우 $43.71 \%$ 로 알곡에 비 해 발아 귀리는 $112 \%$ 가량 더 높았다. 귀리 알곡보다 발아 귀리에서 총 폴리페놀 양이 약 $60 \%$ 증가한데 비해 항산화능력은 무려 $112 \%$ 로 두 배 이상 증가하는 원인으로는 발아 과정에서 생성되는 아베난쓰라 마이드 때문으로 볼 수 있다. Xu et al. (2009)에 의하면 귀리가 발아 하는 동안 총 폴리페놀 양이 증가하여 항산화 활성이 증가한다고 보
A

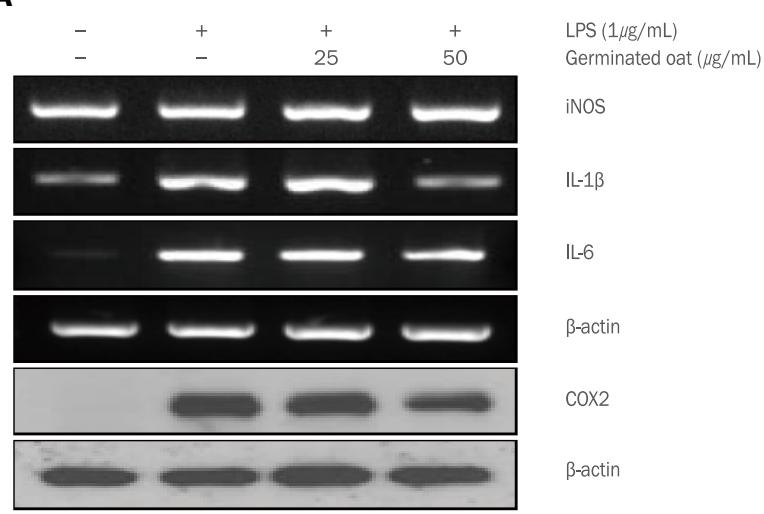

B

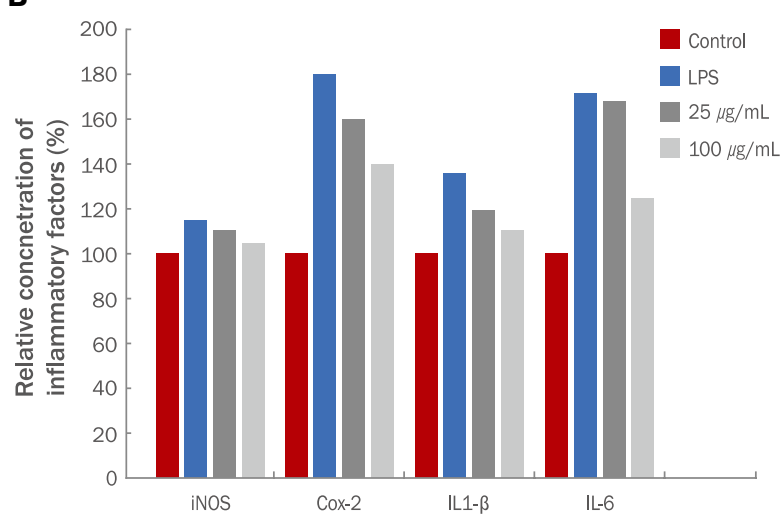

Figure 4. Effect of germinated Avena sativa extract on the expression of iNOS, IL-1ß, IL-6, and COX-2 in the culture of RAW264.7 stimulated with LPS.

RAW 264.7 macrophages were cultured in 6-well plates and treated with LPS and indicated dose of germinated oat grain extracts. Inflammatory factors such as iNOS, IL-1ß, IL-6, and COX-2 were of the germinated oat grain extracts were assayed to evaluate the antiinflammatory effects. (A) Western blot tests were conducted to evaluate the related protein expression levels of inflammatory factors. (B) The graphs of respective densitometric quantification of protein expression have been normalized against $\beta$-actin. Each bar shows mean \pm SD from three independent experiments. ${ }^{*} p<0.05$ compared with control. 


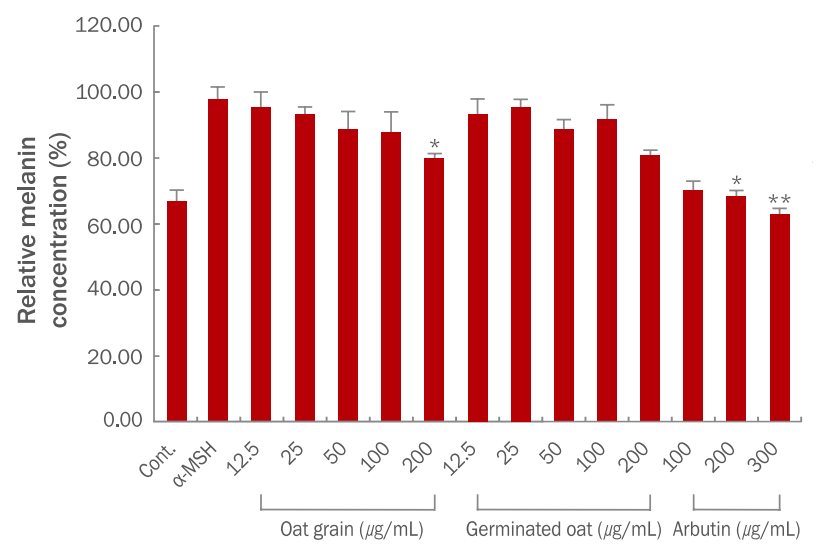

Figure 5. Effect of Avena sativa extract on the melanogenesis in the culture media of B16F10 stimulated with $\alpha-\mathrm{MSH}$.

Melanocytes were cultured in 96-well plates and treated with $\alpha-\mathrm{MSH}$ to determine the dose of oat grain extracts. Melanin was assayed to evaluate its effect on anti-melanogenesis. Dosedependent and oat extract-treated melanocytes decreased melanin production. Arbutin was used as a positive control. Each bar shows mean \pm SD from three independent experiments. ${ }^{*} p<0.05$ compared with control.

이드 농도가 증가할 때가 훨씬 더 효과적으로 항산화활성이 증가함 을 알 수 있다. 발아 전 귀리 추출물에는 ferulic acid, gentisic acid, phydroxybenzoic acid, protocatechuic acid와 같은 폴리페놀류들이 많고, 발아 후에는 이들이 아베난쓰라마이드 형태로 변화하므로 결 과적으로 발아 과정에서 항산화활성이 증가한다는 것이다. 따라서 높은 항산화 활성을 갖는 귀리 추출물을 얻기 위해서는 알곡보다 발 아귀리 추출물이 더 유리하다고 볼 수 있다.

\section{3. 발아 귀리 추출물에 의한 항염 효과 변화}

화장품 소재로서 항염 효과는 매우 많은 관심을 받아왔다(Shim, 2019; Jung \& Ryu, 2018; Seo et al., 2018). 이는 화장품의 중요 기능 중 하나가 피부의 문제를 완화시키는 데 있기 때문이다. Figure 3은 LPS로 자극 받은 RW264.7 세포에서 귀리 추출물이 염증유발 물질인 $\mathrm{NO}$ 의 생성을 효과적으로 억제할 수 있음을 보여주는 것이 다. 귀리 추출물 $100 \mu \mathrm{g} / \mathrm{mL}$ 농도에서 알곡의 경우 $30.36 \%$, 발아귀 리의 경우 $43.67 \%$ 의 $\mathrm{NO}$ 생성 억제 효과를 보여주고 있다. 즉 알곡 보다 발아 귀리의 경우 $\mathrm{NO}$ 생성 억제력이 약 $43 \%$ 증가한 것으로 볼 수 있다. 발아 귀리 추출물이 NO 생성에 관련된 효소인 iNOS와 염증 반응의 시작 효소인 $\mathrm{COX}-2$ 의 발현에 미치는 영향을 조사한 결과는 Figure 4 와 같다. 발아 귀리 추출물 $100 \mu \mathrm{g} / \mathrm{mL}$ 농도에서 iNOS의 발 현에는 별다른 영향을 미치지 못하였으나 COX-2의 발현은 $22 \%$ 이 상 감소시키는 효과를 보여 발아 귀리 추출물이 염증 반응의 시작을 효과적으로 막을 수 있다는 것을 보여주고 있다. 따라서 이러한 염증 반응의 매개체로 활동하는 염증 인자인 $\mathrm{IL} 1-\beta$ 와 $\mathrm{IL}-6$ 의 생성에도

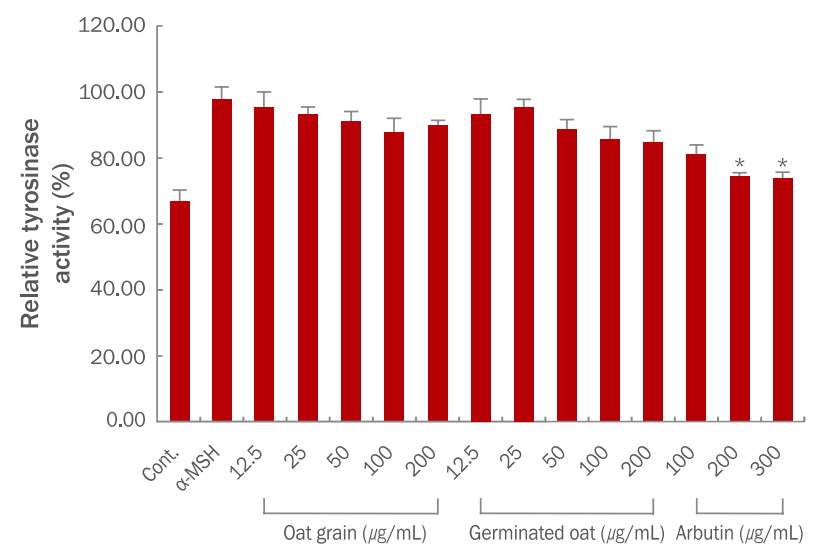

Figure 6. Effect of Avena sativa extract on the mushroom tyrosinase activity.

Mushroom tyrosinase activity was assayed using L-DOPA to evaluate the antimelanogenesis effect of antimelanogenesis. Dose-dependent and oat extract melanocytes decreased tyrosinase activity. Arbutin was used as the positive control. Each bar shows the mean $\pm S D$ from three independent experiments. ${ }^{*} p<0.05$ compared with control.

영향을 미칠 수 있는 데 실제로 발아 귀리 추출물이 $\mathrm{IL} 1-\beta$ 와 IL-6 의 발현을 각각 $17.5 \%$ 와 $22 \%$ 까지 감소시키는 것으로 나타났다. 이 처럼 발아 귀리 추출물이 염증인자들의 생성을 효과적으로 억제할 수 있는 이유는 아베난쓰라마이드를 포함한 폴리페놀류들이 NO 생 성의 첫 단계인 $\mathrm{NF}-\kappa b$ transcription factor의 활성화를 효과적으 로 억제하기 때문이다(Guo et al. 2008; Yang et al., 2014; Perrelli et al., 2018; Kang et al., 2018; Tripathi et al., 2018; Turrini et al., 2019). Kang et al. (2018)에 따르면 tert-butyl hydroperoxide

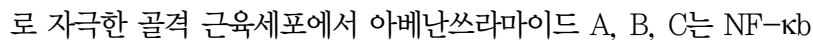
의 활성화 과정에서 생성되는 $\mathrm{IKK} \beta$ 와 결합하여 $\mathrm{IkB}$ kinase의 활성 화를 억제하고 이어지는 하류단계에서 $\mathrm{COX}-2$ 발현과 $\mathrm{PGE}_{2}$ 발현을 차례로 억제한다고 보고 하였다. 또 최근 Dhakal et al. (2019)은 발 아 귀리에서 분리한 아베난쓰라마이드 $\mathrm{C}$ 가 $\mathrm{IgE}$ 로 자극한 mast cell 에서 PI3 kinase와 PLC $\gamma 1$ 의 활성화를 억제하고 동시에 세포 내 칼 슘의 농도를 낮춤으로서 mast cell의 degranulation과 염증 인자인 $\mathrm{IL} 1-\beta$ 와 $\mathrm{IL}-6$ 의 생성을 억제한다고 보고 하였다. 이처럼 귀리 추출 물이 피부의 다양한 염증 부위를 개선하는데 효과가 있다고 알려지면 서 귀리 추출물을 이용한 아토피 개선 화장품 개발이 활발해지고 있 다. Fowler (2014)은 귀리 콜로이드가 들어간 수분크림을 이용하여 12-60세의 아토피 환자 50명을 관리했을 때 2주 후부터 가려움증 이 개선되었고, 4 주 후에는 염증부위가 $40 \%$ 가령 감소했다고 보고하 고 있다. 그 밖에도 다양한 논문들에서 귀리 추출물이 아토피 환자의 피부 염증 부위 완화와 피부 장벽 개선에 도움을 준다고 보고하고 있 다(Wollenberg et al., 2018; Agüero et al., 2006; Tessemaa et al., 2017). 


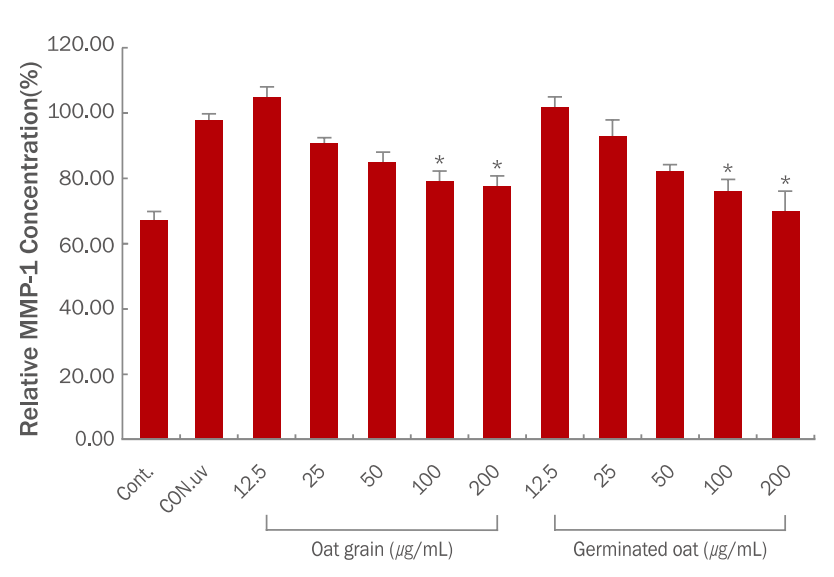

Figure 7. Effect of Avena sativa extract on the production of matrix metaloproteinase-1 (MMP-1) in the culture media of Ultraviolet (UV) irradiated human dermal fibroblasts (HDF).

Fibroblasts were cultured in 96-well plates and treated with Ultraviolet B (UVB) and indicated a dose of the oat grain extracts. The expression level of MMP-1 was assayed using enzyme-linked immunosorbent assay test to evaluate the anti-aging effect. Dosedependent and oat extract-treated human dermal fibroblasts decreased the MMP-1 expression. Each bar shows the mean \pm SD from three independent experiments. ${ }^{*} p<0.05$ compared with control.

\section{4. 귀리 추출물에 의한 멜라닌 생성 저해 효과}

멜라닌 생성을 억제하는 효과는 화장품 원료 물질로서 매우 중요 한 효과 중 하나이다. 앞서 귀리 추출물이 $\mathrm{NF}-\mathrm{Kb}$ 의 활성화를 억제 하는 효과가 있다는 보고가 있었으므로 멜라닌 생성 저해 효과도 함 께 있을 것으로 판단되어 귀리 추출물의 멜라닌 생성 저해 효과에 대 하여 실험을 진행하였다(Figure 5) 그 결과, 귀리 추출물 농도 100 $\mu \mathrm{g} / \mathrm{mL}$ 에서 알곡의 경우 $10.43 \%$, 발아 귀리의 경우 $9.6 \%$ 의 멜라닌 생성 억제 효과를 나타내었다. 이처럼 귀리 추출물들이 높은 항산화 능력을 보이는데 반해 멜라닌 생성 억제력은 $10 \%$ 미만으로 낮게 나 타난 것에 대해서는 현재 설명이 다소 어렵다. 다만 $\alpha-\mathrm{MSH}$ 로 자극 한 $\mathrm{B} 16 \mathrm{~F} 10$ 세포에서 $\mathrm{NF}-\mathrm{Kb}$ 의 활성화 외의 다른 경로로도 멜라닌 생성이 시작될 수 있음을 감안해 볼 때 $\mathrm{NF}-\kappa \mathrm{b}$ 의 활성화 억제가 반 드시 멜라닌 생성 억제로 이어지는 것은 아닐 것이다. 귀리 추출물들 이 멜라닌 생성에 관여하는 효소인 tyrosinase의 역가에 미치는 영향 을 조사하기 위하여 mushroom tyrosinase를 이용하여 tyrosinase 활성 저해 효과를 조사한 결과는 Figure 6과 같다. 그 결과, 귀리 추출물 농도 $200 \mu \mathrm{g} / \mathrm{mL}$ 에서 알곡의 경우 $17.9 \%$, 발아 귀리의 경 우 $19.9 \%$ 의 멜라닌 생성 억제 효과를 나타내어 $30 \%$ 이상 저해하는 arbutin에 비해서는 다소 낮은 tyrosinase 활성 저해 효과를 나타내 었다.

\section{5. 귀리 추출물에 의한 MMP-1 발현 억제 효과}

피부 섬유아 세포는 자외선에 노출되거나 활성 산소종의 자극을
받게 되면 $\mathrm{MMP}-1$ 라는 일종의 콜라겐 분해 효소를 분비하여 조직 내에서 변성된 콜라겐들을 분해하기 시작한다. 이렇게 분해된 콜라 겐들은 섬유아 세포가 새로운 콜라겐을 생성하는데 필요한 신호전 달 물질로 이용되며, 이러한 방법을 통하여 낡은 콜라겐 메트릭스 를 새로운 콜라겐으로 대체하게 된다. 그러나 반복되는 콜라겐 분해 를 미처 보충하지 못할 경우 진피층의 콜라겐 메트릭스가 느슨해지 면서 피부에 잔주름이 형성될 수 있다. 따라서 화장품 속에 들어있는 항산화 물질들이 MMP-1 효소들의 발현을 적절하게 억제하여 피부 의 노화를 막고 섬유아 세포를 보호할 수 있다면 매우 우수한 항노 화 화장품이 될 수 있을 것이다. 본 실험에서는 귀리 추출물들이 자 외선으로 자극 받은 섬유아세포에서 MMP-1 발현을 억제할 수 있 는지 여부를 조사하였다(Figure 7). 그 결과, 귀리 추출물 $100 \mu \mathrm{g} /$ $\mathrm{mL}$ 농도에서 대조군에 비해 알곡의 경우 $29.2 \%$, 발아 귀리의 경우 $28.8 \%$ 정도의 MMP-1 발현을 억제하는 것으로 나타나 대체로 $30 \%$ 미만의 MMP-1 발현 억제 효과를 보였다. 이 수치는 $50 \%$ 이상 억제 가 가능한 다른 식물 추출물들에 비하면 다소 낮은 수치이기는 하나 (Golulanan et al. 2019), 귀리 추출물이 들어간 화장품을 장기간 사 용할 경우 항노화 효과를 기대할 수 있을 것으로 보인다.

\section{Conclusion}

귀리 추출물은 매우 우수한 항산화력을 가지고 있어 그 동안 서유 럽을 중심으로 화장품 원료 물질로 이용되어 왔다. 발아 과정은 곡류 의 화학적 성분을 광범위하게 변화시킨다는 보고에 따라 본 연구에 서는 화장품 원료로서 발아 귀리 추출물의 생리활성 특성을 조사하 였다. 그 결과, 귀리 알곡은 발아과정에서 아베난쓰라마이드 농도가 증가하는 것으로 나타났으며, 이에 따라 항산화활성도 알곡에 비해 발아 귀리에서 2 배 이상 증가하는 것으로 나타났다. 이는 발아 과정 에서 새롭게 생성되는 아베난쓰라마이드의 효과인 것으로 판단된다. 또 귀리 추출물은 염증 유발 물질인 $\mathrm{NO}$ 생성을 효과적으로 억제하였 으며, 발아 귀리 추출물에서는 $43 \%$ 증가된 NO 생성 억제력을 나타 내어 귀리 알곡보다 발아 귀리에서 항산화력과 항염력이 전반적으로 증가하는 것으로 나타났다. 한편, 귀리 추출물의 멜라닌 생성 억제 효과와 tyrosinase 활성 억제 효과에 대해서도 조사하였으나 멜라닌 생성 억제 효과는 비교적 약하게 나타났다. 마지막으로, 귀리 추출물 의 콜라겐 매트릭스 분해 효소인 MMP- 1 발현 억제 효과를 조사하 였으며, 귀리 알곡과 발아 귀리에서 $30 \%$ 정도로 MMP-1 발현을 억 제하는 것으로 나타났다. 이상의 실험 결과들을 종합해 볼 때, 귀리 알곡보다는 발아 귀리 추출물이 보다 더 높은 항산화력과 함께 우수 한 항노화 화장품 원료 물질로 이용 될 수 있을 것으로 사료된다.

\section{Author's contribution}

JUH and TBC designed all experimental investigations, 
and collected data. YHY contributed to all aspects of analysis and experimental design.

\section{Author details}

Ji U Hwang (Student), Major in Cosmetic Biology, Department of Bioengineering, Konkuk University, 120 Neungdong-ro, Gwangjin-gu, Seoul 05029, Korea; Yung Hun Yang (Professor), Major in Cosmetic Biology, Department of Bioengineering, Konkuk University, 120 Neungdong-ro, Gwangjin-gu, Seoul 05029, Korea; Tae Boo Choe (Research Director), Cosmetics Research Center, Ozbiotech, 6th floor, Suan Building, 204 Sunwhan-ro, Jungwon-gu, Seongnam-si, Gyeonggi-do 13204, Korea.

\section{References}

Agüero L, Sesar MD, Pizzorno L, Vilella F, Stella AM. Utilization of Avena sativa extract in dermatitis. Revista Argentina de Dermatología, 87: 100-105, 2006.

Bamforth CW, Barclay AHP. Malting technology and the uses of malt. In: Barley: chemistry and technology. MacGregor, AW, Bhatty RS (eds), American Association of Cereal Chemists, St Paul, Minnesota, pp297-354, 1993.

Blois MS. Antioxidant determinations by the use of stable free radical. Nature, 18: 1199-1200, 1958.

Dhakal H, Yang EJ, Lee S, Kim MJ, Baek MC, Lee B, Park PH, Kwon TK, Khang D, Song KS, et al. Avenanthramide C from germinated oats exhibits antiallergic inflammatory effects in mast cells. Scientific Reports, 9: 6884, 2019.

Fowler JF Jr. Colloidal oatmeal formulations and the treatment of atopic dermatitis. Journal of Drugs in Dermatology, 13: 1180-1183, 2014.

Golulanan EM, Nemutlu E, Demirezer LO. A new perspective on evaluation of medicinal plant biological activities: The correlation between phytomics and matrix metalloproteinases activities of some medicinal plants. Saudi Pharmaceutical Journal, 27: 446-452, 2019.

Greenstock CL. Radiation and aging: free radical damage, biological response and possible antioxidant intervention. Medical Hypotheses, 41: 473-482, 1993.

Guo W, Wise ML, Collins FW, Meydani M. Avenanthramides, polyphenols from oats, inhibit IL-1 $\beta$-induced NF-KB activation in endothelial cells. Free Radical Biology and
Medicine, 44: 415-429, 2008.

Gutfinger T. Polyphenols in olive oils. Journal of American Oil Chemists Society, 58: 966-968, 1981.

Jung YH, Ryu MJ. Anti-oxidative and anti-inflammatory effects of Codonopsis lanceolate skin extracts. Asian Journal of Beauty and Cosmetology, 16: 347-357, 2018

Kang C, Shin WS, Yeo D, Lim W, Zhang T, Ji L. Antiinflammatory effect of avenanthramides via NF-KB pathways in $\mathrm{C} 2 \mathrm{C} 12$ skeletal muscle cells. Free Radical Biology and Medicine, 117: 30-36, 2018.

Katina K, Liukkonen KH, Kaukovirta-Norja A, Adlercreutz $\mathrm{H}$, Heinonen SM, Lampi AM, Pihlava JM, Poutanen K. Fermentation-induced changes in the nutritional value of native or germinated rye. Journal of Cereal Science 46: 348-355, 2007.

Liu L, Zubik L, Collins FW, Marko M, Meydani M. The antiatherogenic potential of oat phenolic compounds. Atherosclerosis, 175: 39-49, 2004.

Maydani M. Potential health benefits of avenanthramide of oats. Nutrition Reviews, 67: 731-735, 2009.

Moreno MI, Isla MI, Sampietro AR, Vattuone MA. Comparison of the free radical scavenging activity of propolis from several region of Argentian. Journal of Enthrophamacology, 71: 109-114, 2000.

Perrelli A, Goitre L, Salzano AM, Moglia A, Scaloni A, Retta SF. Biological activities, health benefits, and therapeutic properties of avenanthramides: from skin protection to prevention and treatment of cerebrovascular diseases. Oxidative Medicine and Cellular Longevity, 2018: 6015351, 2018.

Seo JY, Kim JS, Kim KL. Anti-inflammatory effects and innate immunity suppression by Fritillaria ussuriensis extracts. Asian Journal of Beauty and Cosmetology, 16: 10-19, 2018

Skoglund M, Peterson D, Anderssonn R, Nilsson J, Dimberg LH. Avenanthramide content and related enzyme activities in oats as affected by steeping and germination. Journal of Cereal Science, 48: 294-303, 2008.

Shim JH. Anti-inflammatory effect of zeaxanthin in RAW264.7 cells. Asian Journal of Beauty and Cosmetology, 17: 431439, 2019

Soycan G, Schär MY, Kristek A, Boberska J, Alsharif SNS, Coron G, Shewry PR, Spencer JPE. Composition and 
content of phenolic acids and avenanthramides in commercial oat products: are oats an important polyphenol source for consumers? Food Chemistry: $X, 3$ : 100047, 2019.

Sur R, Nigam A, Grote D, Liebel F, Southall MD. Avenanthramides, polyphenols from oats, exhibit antiinflammatory, anti-itch activity. Archives Dermatological Research, 300: 569-574, 2008.

Tessemaa EN, Gebre-Mariam T, Lange S, Dobner B, Neubert $\mathrm{RHH}$. Potential application of oat-derived ceramides in improving skin barrier function: Part 1. isolation and structural characterization. Journal of Chromatograpy $B$, 1065-1066: 87-95, 2017.

Tripathi V, Singh A, Ashraf MT. Avenanthramides of oats: medicinal importance and future perspectives. Pharmacognosy Reviews, 12: 66-71, 2018.

Turrini E, Maffei F, Milelli A, Calcabrini C, Fimognari C. Overview of the anticancer profile of avenanthramides from oat. International Journal of Molecular Sciences,
20: 4536, 2019.

Wollenberg A, Fölster-Holst R, Saint Aroman M, Sampogna F, Vestergaard C. Effects of a protein-free oat plantlet extract on microinflammation and skin barrier function in atopic dermatitis patients. Journal of the European Academy of Dermatology and Venereology, 32: 1-15, 2018.

Xu J, Tian C, Hu Q, Luo J, Wang X, Tian X. Dynamic changes in phenolic compounds and antioxidant activity in oats (Avena nuda L.) during steeping and germination Journal of Agricultural and Food Chemistry, 57: 1039210398, 2009.

Yang J, Ou B, Wise M, Chu Y. In vitro total antioxidant capacity and anti-inflammatory activity of three common oat-derived avenanthramides. Food Chemistry, 160: 338-345, 2014. 


\section{국문초록}

\section{화장품 소재로서 발아 귀리 추출물의 생리활성 특성}

황지우 ${ }^{1}$, 양영헌 $^{1}$ 최태부 ${ }^{2 *}$

${ }^{1}$ 건국대학교 공과대학 생물공학과 향장생물학전공, 서울, 한국

${ }^{2}$ 오즈바이오텍 향장과학연구소, 경기도 성남시, 한국

목적: 본 연구에서는 귀리의 발아 전·후에 변화하는 항산화 활성과 항염 효과에 대하여 조사, 비교함으로써 새로운 화장품 소재로 서의 가능성을 알아보았다. 방법: 국내산 귀리알곡을 동결 건조한 후 $95 \%$ 에탄올로 추출, 건조시켜 귀리 추출물을 획득하였다. 발 아 귀리 추출물은 알곡을 $20^{\circ} \mathrm{C}$ 에서 5 일간 발아시킨 뒤 동일한 방법으로 준비하였다. 이렇게 획득한 귀리 및 발아 귀리 추출물을 세 포 배양에 적용하여 항산화 활성, 항염 활성, 항멜라닌 활성 그리고 항노화 활성을 측정하였다. 결과: 발아 후 귀리는 발아 전 귀리 에 비해 $\mathrm{DPPH}$ 소거활성이 $112 \%$ 증가하여 2 배 이상 더 높았으며, $\mathrm{NO}$ 생성억제 효과는 $43 \%$ 증가하였다. 발아 귀리 추출물의 경우 $\mathrm{LPS}$ 로 자극받은 RAW 264.7 세포에서 $\mathrm{Cox}-2$ 의 발현을 $35 \%$ 이상, 그리고 $\mathrm{L} 1-\beta$ 와 $\mathrm{L}-6$ 의 생성은 각각 $17.5 \%$ 와 $22 \%$ 까지 감소시 키는 것으로 나타나 염증 반응 관련 인자들을 효과적으로 억제하였다. 이러한 효과는 발아 과정에서 증가하는 아베난쓰라마이드 때 문인 것으로 보인다. 결론: 이상의 결과로 보아 발아 귀리는 발아 전 귀리에 비해 항산화 활성이 우수하고 높은 항염 효과를 가지는 것으로 보인다. 따라서 발아 귀리는 우수한 항염 효과를 나타내는 화장품 소재로 개발이 가능하다.

핵심어: 귀리 추출물, 발아, 아베난쓰라마이드, 항염, 화장품 소재

\section{참고문헌}

서진영, 김정숙, 김금란. 평패모 추출물의 항염효과와 선천 면역반응 억제. 아시안뷰티화장품학술지, 16: 10-19, 2018. 심중현. 제아잔틴에 의한 Raw264.7 세포에서의 항염효과. 아시안뷰티화장품학술지, 17: 431-439, 2019. 정윤희, 유민정. 더덕 껍질 추출물의 항산화 및 항염증 효과. 아시안뷰티화장품학술지, 16: 347-357, 2018. 


\section{中文摘要}

\section{发芽燕麦 (Avena sativa) 提取物作为化妆品原料的生理特性}

黃智優 ${ }^{1}$, 梁泳憲 $^{1}$, 崔泰富 $^{2+}$

建国大学生物工学科香妆生物学专攻, 首尔, 韩国

${ }^{2}$ Ozbiotech 香妆科学研究所, 京畿道城南市, 韩国

目的: 本研究评估了发芽和未发芽燕麦 (Avena sativa) 谷物的抗氧化和抗炎能力, 以开发新的化妆品原料。 方法：将一些局部燕麦粒冷冻干燥（冷冻干燥），用95\%乙醇提取，得到发芽的燕麦，再经干燥得到未发芽 的燕麦提取物。燕麦粒在 $20^{\circ} \mathrm{C}$ 下发芽 5 天, 并按照上述相同步骤提取。随后, 将提取物应用于培养的细胞, 以 确定其抗氧化，抗炎，抗黑色素生成和抗衰老作用。结果：与发芽燕麦相比，发芽燕麦提取物的1,1-二苯基-2吡啶-2-肼基（DPPH）自由基清除活性和一氧化氮（NO）生成抑制能力分别提高了112\%和43\%。未发芽。 用脂多糖（LPS）刺激的RAW264.7细胞显示, 用发芽的燕麦提取物处理可分别下调炎症因子（如环氧合酶 2 , 白介素 $1 \beta$ 和白介素6）的表达，分别下调35\%，17.5\%和 $22 \%$ 。这种增强的抗炎作用可能是由于发芽期间 avenanthramide增加所致。结论: 发芽的燕麦籽提取物具有增强的抗氧化和抗炎特性。因此，发芽燕麦粒的提 取物可以成为化妆品工业的良好原料来源。

关键词: 燕麦提取物, 发芽, 阿南酰胺, 消炎, 化妆品原料 